\title{
Biotechnology for the Environment
}

\author{
A report on the \\ Joint United States - European Union \\ Celebration of a Decade of Environmental Biotechnology Exchange \\ Activities for Early Career Scientists \\ Project ID: 0011751 \\ Submitted by: \\ Joseph M. Suflital and Judy D. Wall ${ }^{2}$ \\ 'Department of Botany \& Microbiology, University of Oklahona \\ ${ }^{2}$ Biochemistry Department, University of Missouri-Columbia
}

Program Manager: Daniel W. Drell Division: SC-23.1

Award Register\#: ER640950011751 
The joint EU-US Task Force on Environmental Biotechsology held a workshop entitled, "A Celebration of a Decade of Environmental Biotechnology Exchange Activities" on October 17, 2005 in Brussels, Belgium. This was a fitting venue since Brussels was where the EU-US transatlantic initiative originated. The workshop brought together fomer trainees who are currently active in the field of environmental biotechnology in order to 1) assess the impact of the past training activities; 2) to promote further collaborations; and 3) to highlight working group and task force activities in this field. Presentations by the early career scientists filled the meeting day (see Appendjx I and II for meeting agenda and abstract book, respectively). Task Force members chaired the various sessions. An additional poster session provided an opportunity for more intensive scientific exchange. The day culminated with a formal dinner and gathering of all participants. Agencies supporting the activities included DOE, USDA and NSF. Funds received from the DOE were exhausted and USDA and NSF allowed the Task Force to use unexpended monies (via no cost extensions) to facilitate future fellowship exchange activities.

Over the past ten years, there bas been a high level of sensitivity for working collaboratively with European colleagues. This philosophy simply pervades each and every activity of the EU-US Task Force. Realistically, this means that there is a careful balance between the US and EU participation in all functions. The Brussels 'Celebration' workshop was no exception. The organizers anticipated funding more former U.S. trainees than actually attended the workshop and raised the necessary funds to accomplish this goal. However, the number of U.S. attendees needed to be tempered since the financial resources for our EU counterparts proved more difficult to obtain. In order to maintain the scholarly and political balance on the program of events, fewer U.S. attendees were invited.

Details of the expenditure of DOE funds are provided in the Table 1. As indicated in the original proposal, funds were used to support both past trainees (Treves, Leigh, Buchan, Bender, Penez-Jimenez, Becker, and Methe) as well as Task Force members (Zylstra, Suflita, Wall). The general assessment by the trainees was that the past Task Force activities were crucial to their development as scientists. The prevailing feeling was that they wished that more individuals could profit from similar experiences. 
There was aiso a high degree of enthusiasm for the trainees to get involved in some way with the Task Force activities. That is, the celebration lead to the orgenization of our former trainees to serve in an advisory capacity for future endeavors. In addition, the gathering served as an opportunity to plan for another two week environmental biotechnology course at Rutgers. 
Table 1. Accounting of DOE funds supporting US participants in the joint EU-US Task Force on Environmental Biotechnology workshop entitled, "A Celebration of a Decade of Environmental Biotechnology Exchange Actjvities" in Brussels, Belgium.

\section{Participant}

Heath Mils

David Treves

Mary Beth Leigh

Alison Buchan

Kelly Bender

Jose Perez-Jimenez

Josie Becker

Judy Wall

Gerban Zylestra

Joseph Suflita

Barbara Methe

TOTAL

\section{Disbursement (\$)}

$$
1,773.77
$$

$1,611.72$

$1,936.79$

$1,763.78$

I, 626.25

$1,752.49$

592.06

$1,640.89$

$1,752.15$

2,085.41

1.464 .69

$\$ 18,000$ 
Appendix I - Meeting Agenda 
Appendix II - Abstracts of Presentations 
EC-US Biotechnology Task Force on Biotechnology Research

Working Group on Biotechnology for the Environment

"A Celebration of a Decade of Environmental Btotechnology Exchange Activities" Monday, 17 October 2005

Venue: European Commission

CCAB Centre Albert Borscbette, room 4D

rue Froissart, 36

B-1040 Bruxelles

8.30 Registration

9.00 Welcome and Opening Remarks

C. Patertuann, EC

Anna Palmisano, US

Session Chairs: S. Agathos (U. Louvain, BE) and J. Suflita (U. Oklahoma, USA)

9.30 Barbara Methe (TIGR, USA) The application of genomic and functional genomics approaches to the study of environmentally relevant prokaryotes

10.00 Ildefonso Cases (CSIC, Madria, ES) title to be determined

10.30 Dave Treves (U. Indiana, USA) Microbial dynamics and diversity in Pluto Spring, a sulfur-enriched mineral spring in central indiana

11.00 Ivonne Nijenhuis (UFZ, Leipzig, DE) Assessment of natural attenuation of chiocinated ethenes using stable isotope techniques, microcosm studies and molecular markers

11.30 Kelly Bender (U. Missouri-Columbia, USA) The three FUR homologs of Destlfovlbrlo vulgarts Hildenborough; Insights into global regulation of sulfateređucing bacteria

12.00 Balbina Nogales (U. Illes Balears, Palma de Mallorea, ES) Mjerobial diversity and functionality in polluted marine ecosystems

12.30 Lunch

Session Chairs: Judy Wall (U. Missouri-Columbia, USA) and Juan Ramos (CSIC, Granada, ES)

13.30 Josey Becker (Purdue U., USA) Culturable biodiversity within the soil from a longterm contaminated site using a newly developed soil incubation chamber

14.00 Gumnar Overgaard (U. Copenhagen, DK) Cultivation-independent enumeration of mercury resistant bacteria from soil environments - pros and cons of quantitative real time PCR 
15.00 Giulio Zanaroli (U. Bologna, [T) Enrichment and characterization of a PCB dechlorinating community in anaerobic slurry microcosms of a Venice lagoon sediment.

15.30 Poster session and coffee

16.30 Group Discassion: Barbara Methe (TIGR, USA) and Victor de Lorenzo (CSIC, Madrid, ES), moderators

What is the future of Environmental Biotechnology? Where are the scientiffc opportunities?

What training activities should the Working Group support for early career scientists in Environmental Biotechnology over the next 10 years?

17.30 Closing remarks

loannis Economidis, EC

19.30 Dinser at the Hotel Leopold (Rue de Luxembourg) 
EC-US Biotechmology Task Force on Biotechnology Research

Working Group on Biotechnology for the Environment

\section{"A Celebration of a Decade of Environmental Biotechnology Exchange Activittes" Monday, 17 October 2005 \\ Venue: European Commission \\ CCAB Centre Albert Borschette, room 4D \\ rue Froissart, 36 \\ B-1040 Bruxelles}

\subsection{Registration}

9.00 Welcome and Opening Rernarks

C. Patermann, EC

Anna Palmisano, US

Session Chairs: S. Agathos (U. Loavain, BE) and J. Suflita (U. Oklahoma, USA)

9.30 Barbara Methe (TIGR, USA) The application of genomic and functional genomics approaches to the study of environmentally relevant prokaryotes

10.00 Ildefonso Cases (CSIC, Madrid, ES) title to be detemined

10.30 Dave Treves (U. Indiana, USA) Microbial dynamics and diversity in Pluto Spring, a sulfur-enriched mineral spring in central Indiana

11.00 Ivonne Nijenluvis (UFZ, Leipzig, DE) Assessment of natural attenuation of chlorinated ethenes using stable isotope techniques, microcosm studies and molecular markers

11.30 Kelly Bender (U. Missauri-Columbia, USA) The three FUR bomologs of Desulfovtbrio valgarts Hildenborough: Insights into global regulation of sulfatereducing bacteria

12.00 Balbina Nogales (U. Illes Balears, Palma de Mallorca, ES) Microbiai diversity and functionality in polluted marine ecosystems

12,30 Lunch

Session Chairs: Judy Wall (U. Missouri-Columbia, USA) and Juan Ramos (CSIC, Granada, ES)

13.30 Josey Becker (Purdue U., USA) Culturable biodiversity within the soil from a long* term confaminated site using a newly developed soil incubation chamber

14.00 Gunnar Overgaard (U. Copenhagen, DK) Cultivation-independent emumeration of mercury resistant bacteria from soil environnents - pros and cons of quantitative real time PCR 
15.00 Giulio Zanaroli (U. Bologna, IT) Enrichment and characterization of a PCB dechlorinating community in anaerobic sturty microcosms of a Venice lagoon sediment.

15.30 Poster session and coffee

16.30 Group Discussion: Barbara Methe (TIGR, USA) and Victor de Lorenzo (CSIC, Madrid, ES), moderators

What is the future of Environmental Biotechnology? Where are the scientific opportunities?

What training activities should the Working Group support for early career scientists in Environmental Biotechrology over the next t0 years?

I7.30 Closing remarks

Ioannis Econonidis, EC

19.30 Dinner at the Hotel Leopold (Rue de Luxembourg) 